\title{
PLS 回帰分析を用いた重み付きー般化 Hough 変換*
}

\author{
犬飼純平 $^{* *}$ 加藤邦人 ${ }^{* * *}$ David Harwood ${ }^{\dagger}$ Larry S. Davis ${ }^{\dagger}$
}

Weighted Generalized Hough Transform by Using Partial Least Squares Regression Analysis

Junpei INUKAI, Kunihito KATO, David Harwood and Larry S. Davis

\begin{abstract}
This paper proposes extended Generalized Hough Transform (GHT) to introduce training process by using Partial Least Squares (PLS) regression analysis. Hough transform can robustly detect patterns against noise and occlusions, and GHT is adapted to perform the generic object detection. However, GHT has a weak point in detecting object shape change. Thus, we introduced a training process to determine the voting weight of GHT by using PLS regression analysis. We call our method "PLS Hough transform". Thereby, it becomes possible to generic object detection, while maintaining the framework of Hough-based object detection. Also, features are selected by Variable Influence on Projection (VIP) or regression coefficient obtained by PLS regression analysis. To confirm the effectiveness of our method, we applied PLS Hough transform to the vehicle detection from aerial and satellite images.
\end{abstract}

Key words: generalized hough transform, partial least squares regression analysis, feature selection, vehicle detection

\section{1. 緒言}

コンピュータビジョンの分野において, 画像中から顔や人な どを検出する物体検出手法として, これまで様々な方法が提案 されてきた. その中で最も広く知られているものがテンプレー トマッチングである. テンプレートマッチングでは, 検出したい 物体のテンプレートを作成することで学習を行い, テンプレー トと入力画像中の局所領域の相関を求めることにより検出を行 う. そのため, 検出対象の図形が一部暚蔽している場合などには 高精度な検出が困難であるという問題点がある.

一方, Hough 変換 ${ }^{1}$ は数式で表すことのできる直線や円などの 図形に対しパラメータ変換を行うことで, ノイズや隠蔽による 画素の欠落に影響を受けることなく検出できる手法として知ら れている. Hough 変換の研究は長い歴史を持ち, 今日までに様々 な研究が行われてきた ${ }^{2-4)}$.これらの中で, 数式で表すことが困 難な幾何学図形, すなわち一般物体に Hough 変換を適用したも

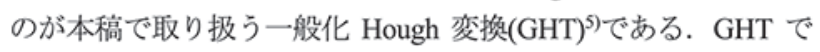
は, 検出したい図形のエッジ方向と基準点までのベクトルを Rtable という定義表に記憶することで, 物体の形状を学習する. 検出時にはこの R-table を参照し, 各エッジ点からの投票処理を 行うことで対象物体を検出する.

しかしながら, GHT は工場の部品や道路標識など形状が固定 された検出対象に対しては信頼性の高い検出が可能であるが, 性質上形状変化に弱く, 多量の画像から物体の特徵を抽出して学 習することが困難とされている. 一方, テンプレートマッチング はさまざまなシーンに合わせた特徴量の抽出, および学習が可 能であり, 非常に拡張性が高いといえる. このようなことから, 近年提案される研究の大多数はテンプレートマッチングに属す るものである. しかし, これらの手法は原理上, ノイズや鿵蔽に 対しての頑健性は弱くなってしまう.

そこで, 本稿では GHT に PLS(Partial Least Squares)回帰分析 ${ }^{\text {) }}$

*原稿受付 平成 29 年 5 月 8 日

掲载決定 平成 29 年 7 月 31 日

*** 岥阜大学 (岐阜県岐阜市柳戸 1-1)

***正会員㞳阜大学

† UMIACS, University of Maryland (College Park, MD 20742, USA)
の回㷌係数を投票重みとして利用した重み付き GHT を提案す る. PLS 回帰分析は, 目的変数と説明変数の相関を最大化する ように次元圧縮を行うことで, 精度の高い回帰モデルを得るこ とができる回帰分析手法の一つである. この PLS 回帰分析を 2 クラス識別に応用すると, 高い識別性能が得られることが知ら れている ${ }^{7}$. さらにPLS 回帰分析で得られた回帰係数, もしく は VIP(Variable Influence on Projection) $)^{8}$ を用いることで, どの特 徵が識別に有効であるのかを評価し, 最適な特徵を選択するこ とができる. 特徴選択を行うことで, 不要な特徵を削除し, 効率 的に計算を行うことができる.

我々は, この GHT と PLS 回帰分析を組み合わせた物体検出 手法を「PLS Hough 変換(PLSHT)」と呼ぶ. また, 精度評価のた めに衛星画像からの自動車検出に適用した. 衛星画像からの自 動車検出は都市計画や, 交通量調査, さらには防犯技術など様々 な分野への応用が期待される. しかし, 自動車検出には多数の難 しさが存在する. 例えば, 車の形状のバリエーションは多様であ り, 木や建物, 影によって一部が隠蔽されているものも存在す る. また, 衛星写真という非常に大きな画像から無数に存在する 小さな車を探索しなくてはならない, そのため, 高精細な衛星画 像が得られるようになってきた一方で, 自動車検出は未だに難 しい問題として扱われている.

本研究では, GHT の投票パターンを特徽量としてPLS 回帰分 析により 2 クラス識別を行い, 衛星画像からの自動車検出に適 用することで性能評価を行う.ささらに回帰係数, VIP を用いて自 動車検出に効果的な特徵選択を行う.

\section{2. 関 連 研 究}

GHT に関する研究は今日までにいくつか提案されてき た.Leavers は投票処理の効率化のために Dynamic GHT ${ }^{9}$ を提案し た. この手法では, 特徵点の選択を確率的に行い, 投票数を減ら すことで, GHT の計算を最適化している. 同様に, 確率を用い て GHT の投票数を減らす手法として, Fung らが提案した Randomized GHT ${ }^{10)}$ がある. Tsai は 2 段階の投票を行う Two-stage GHT ${ }^{11)}$ を提案した. 第 1 段階では物体の回転角度を決定し, 第 2 段階で物体の重心を決定する. 同様に Kimura らによって提案さ 
れた Affine GHT ${ }^{12)} 2$ 段階投票を行うことで物体を検出してい る. これらの手法では, 多段階投票を行うことでパラメータ空間 の次元削減を行っている. 上記の手法では, GHT の計算を効率 的に行うため, 投票処理の改良, パラメータ空間の改良が行われ ている.

Samal らは, Hough transform for natural shapes ${ }^{13)}$ を提案した. ま た, Bonnet によりこの手法が拡張されている ${ }^{14)}$. これらの手法 は，葉などのように形状に個体差が存在する物体を検出対象に したものである. 形状に個体差があった場合でも, 同じクラスの 物体であれば局所的に類似した曲線が存在するという考えを原 則とし, GHT を拡張している. Izadinia らは, GHT に Fuzzy 理 論を導入した Fuzzy GHT ${ }^{15) を}$ を提案した. Fuzzy 理論を導入するこ とで, よりノイズや隠蔽, 歪みに頑健な GHT へと払張した.

GHT に学習を付加するものとして, 局所パッチベースの物体 検出手法が多く提案されている. Leibe らによって提案された Implicit Shape Model ${ }^{16}$ は局所パッチ画像から Codebook を作成す ることで学習を行う. 検出時には Codebook に基づき投票を行い, 物体の重心を抽出する. 他にも Maji らによって提案された SVM ベースのクラス分類を行う Max-Margin Hough transform ${ }^{17) や ~ G a l l ~}$ らによって提案された 2 クラス分類に Random Forest を用いる Hough Forest(HF) ${ }^{18)}$ が有名である. 特に近年では, 精度の高い物 体検出, 姿勢推定手法として HF を拡張したものが多く提案され ている. Gall らはオリジナルの HFを多クラス, 多視点に対応し た物体検出に拡張した ${ }^{19}$. Murai らは Weighted $\mathrm{HF}^{20)}$ を提案して いる.この手法では, ボジティブデータと類似しているネガティ ブデータの影響を抑えるために, 学習サンプルに重みを導入し, 誤検出の低減を可能にしている. Tran らは Fast growing $\mathrm{HF}^{21)}$ 提案し, オリジナルの HF の精度を維持したまま学習にかかる処 理時間を短縮した. また, Tejani らが提案した Latent-class HF ${ }^{22}$ やSahin らの Iterative HF with Histogram of Control Points $\left.{ }^{23}\right)$ は HF を拡張した手法であり, 姿勢推定を高精度に行っている. しかし ながら, 局所パッチベースの物体検出手法はいずれも画像を分 割した局所領域からの投票をベースとしており, 本来エッジ点 ベースで投票を行う Hough 変換の枠組みに収まっておらず， ノ イズや隠蔽に頑健であるという特性が失われてしまう可能性が ある.

本稿では, PLS 回帰分析を用い, GHT の各投票に重み付けを 行うことで, ノイズや鿵蔽に頑健であるという Hough 変換の枠 組みを保ったまま, 形状変化にも対応した物体検出を可能とし た.

\section{3. 提 案 手 法}

\section{1 手法概要}

PLS HT は学習処理と検出処理から構成される. PLS HT の全

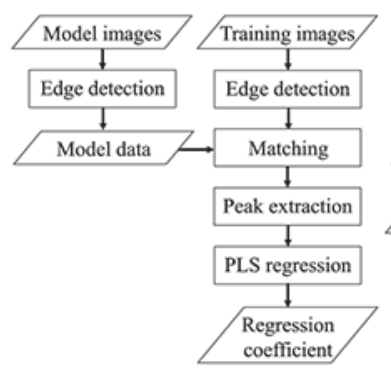

(a) Training process

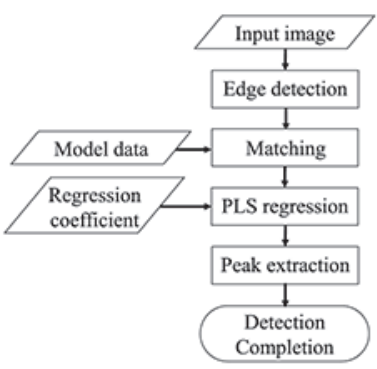

(b) Detection process
Fig. 1 Process of PLS HT
体の流れを図 1 に示す.

学習処理では, GHT の R-table と同様にエッジ方向と基準点 までのベクトルを用いて検出対象の形状を表すモデルデータを 作成する. その後, このモデルデータを用いて学習データに GHT を適用し, 投票パターンを得る. その投票パターンから, どのモ デルからの投票が検出に有効であるかを解析し, 各モデルの重 要度を決定する. モデル点の重要度の解析には PLS 回帰分析を 用いる.

検出処理では, 学習処理で得られた回帰係数を投票重みとし て GHT の投票を行う.

\subsection{PLS 回帰分析}

PLS 回㷌分析は回州モデルを求める際に説明変数と目的変数 のそれぞれについて次元圧縮を行う. 次元圧縮を行う際の圧縮 軸の方向ベクトルをローディング, ローディングに変数を射影 して得られた值をスコアという. ローディングとスコアを図2に 示す. PLS 回帰分析では目的変数と説明変数間のスコアの相関 が最大となるようにそれぞれローディングを決定し, 次元圧縮 を行う。これにより得られたスコアから回帰モデルを作成する ため, 主成分回帰分析よりも精度の高い回帰を行うことができ る. 説明変数と目的変数のローディングをそれぞれ $P, Q$, スコ アを $T, U$ とすると PLS 回帰分析の次元圧縮は図 3 のようにな る.

入力される特徵ベクトルを $X$, 推定值を $y$, 回帰係数を $\boldsymbol{b}$, 特 徵次元数を $L$ とすると得られる回帰モデルは式(1)のようになる.

$$
\begin{gathered}
y=\boldsymbol{X} \boldsymbol{b} \\
y=x_{1} b_{1}+x_{2} b_{2}+\cdots+x_{L} b_{L}
\end{gathered}
$$

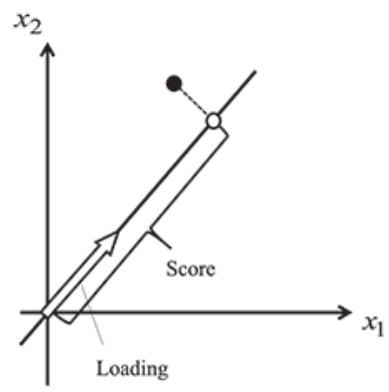

Fig. 2 Schematic representation of the loading and the score
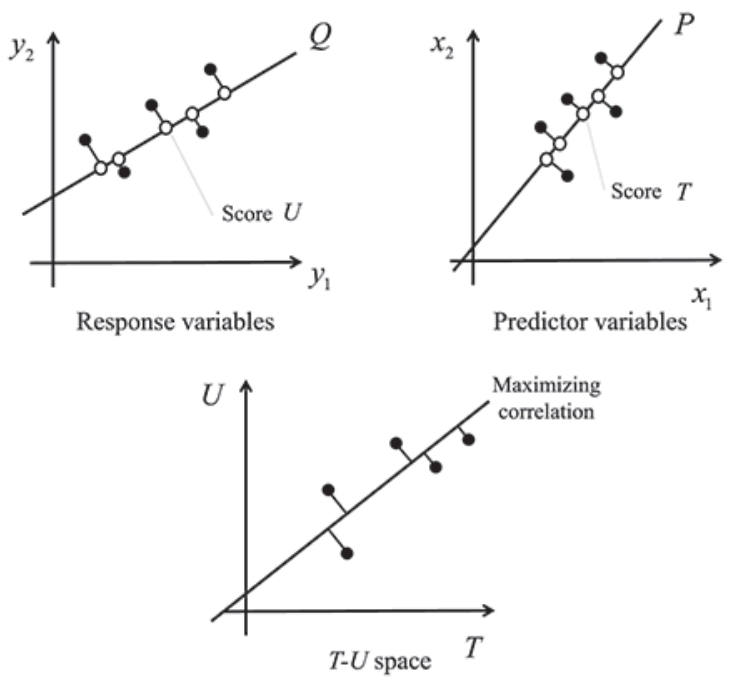

Fig. 3 Dimensionality reduction by PLS regression 
目的変数が一次元である場合の一般的な解法である NIPALS アルゴリズム(PLS1) 24)を以下に記す。

\begin{tabular}{|c|c|c|}
\hline \multirow[t]{9}{*}{ 定義 } & $X$ & : 説明変数 \\
\hline & $y$ & : 目的変数 \\
\hline & $d$ & : 圧縮次元数 \\
\hline & $W$ & : 相関行列 \\
\hline & $T$ & : 説明変数のスコア \\
\hline & $P$ & : 説明変数のローディング \\
\hline & $c$ & : 内部回帰係数 \\
\hline & $b$ & : 回帰係数 \\
\hline & $t$ & : 行列の転置 \\
\hline 1: & \multicolumn{2}{|c|}{ for $i=1$ to $d$ do } \\
\hline 2: & & $W_{i}=X^{t} y /\left\|X^{t} y\right\|$ \\
\hline 3: & & $T_{i}=X W_{i} /\left\|X W_{i}\right\|$ \\
\hline 4: & & $P_{i}=X^{t} T_{i}$ \\
\hline 5: & & $X=X-\left(T_{i} P_{i}{ }^{t}\right)$ \\
\hline 6: & & $c=T_{i}^{t} y /\left\|T_{i} T_{i}^{t}\right\|$ \\
\hline 7: & & $y=y-c T_{i}$ \\
\hline 8: & \multicolumn{2}{|c|}{ end for } \\
\hline 9: & \multicolumn{2}{|c|}{$\boldsymbol{W}^{*}=\boldsymbol{W}\left(\boldsymbol{P}^{\boldsymbol{t}} \boldsymbol{W}\right)^{-1}$} \\
\hline 10: & \multicolumn{2}{|c|}{$b=W^{*}\left(T^{t} T\right)^{-1} T^{t} y$} \\
\hline
\end{tabular}

PLS 回帰分析では, 圧縮次元数によって回㷌モデルの推定精 度が変化し, データごとに最適な圧縮次元数が存在する. そのた め, 交差検定法を用いて最適な圧縮次元数を決定しなければな らない. 交差検定法にはいくつか種類があるが，本研究では Leave-One-Out を用いた.

学習用データから PLS 回帰分析によって回帰モデルを作成し, そのモデルを用いてテスト用データの推定值を算出する. その 推定値と真值の誤差を計算し, 平均推定誤差が最も小さい次元 数を, 最適な圧縮次元数とする.

\section{3 エッジ検出法}

PLS HT では, GHT と同様に画像に対してエッジ検出処理を 行い, そのエッジ点からの投票を行うことで物体を検出する. こ のように, Hough 変換では, 局所的な情報であるエッジ方向特徵 量を用いるため, より正確にエッジを検出する必要がある. そこ で本研究では以下のようなエッジ検出手法を使用する.

このエッジ検出法は大きく二つの処理から構成される. 一つ はエッジ方向を算出するための処理, もう一つは, 細線化された エッジを抽出するための処理である. 我々はこれらのエッジ検 出手法をそれぞれ，Harwood Edge Detector 1(HED1), Harwood Edge Detector 2 (HED2) と呼ぶ.

\section{3. 1 Harwood Edge Detector 1}

HED1 ではSobel フィルタなどと同様にフィルタリング処理に よって注目画素の微分值を算出する. Sobel フィルタが $3 \times 3$ の 8 近傍のフィルタを用いてェッジ方向を算出するのに対し, HED1 では図 4(a)に示すような円状の 20 近傍のフィルタを用い ることで，より高精度にエッジ方向を算出することができる.

まず, 図 4 (a) の同番号 $s(0 \leq s \leq 9)$ の画素の輝度值の差 $f s(s)$ を求める. 図 4 (b)のように, 番号 $s$ が隣り合う 4 画素 $(0$ と 1,2 と $3, \cdots)$ を用いて水平成分, 垂直成分それぞれのベクトルに同 番号間の輝度值の差 $f(s)$ を重みとして足し合わせた $G V_{x}, G V_{y}$ を 算出する. 番号 $s$ 間のベクトルの距離を $v d(s)$, ベクトルの水平
成分を $v x(s)$, 垂直成分を $v y(s)$ とした時, $G V_{x}, G V_{y}$ は式(2)のよう に計算する.

$$
\begin{aligned}
& G V_{x}=f s(s) \times \frac{v x(s)}{v d(s)}+f s(s+1) \times \frac{v x(s+1)}{v d(s+1)} \\
& G V_{y}=f s(s) \times \frac{v y(s)}{v d(s)}+f s(s+1) \times \frac{v y(s+1)}{v d(s+1)}
\end{aligned}
$$

式(2)の計算を 5 パターン $(0$ と 1,2 と $3, \cdots)$ に関して計算し, $G V_{x}, G V_{y}$ をそれぞれ足し合わせ, 5 で除算することで $G V_{x}, G V_{y}$ の平均值 $d x, d y$ を求め, これらを微分值としてエッジ方向を算 出する. 注目画素におけるエッジ方向 $\theta$ は微分值を用いて式(3) より算出する.

$$
\theta=\tan ^{-1}\left(\frac{d x}{d y}\right)
$$

式(2)からも分かるように, 番号 $s$ 間の距離が大きいほど $v d(s)$ の值が大きくなるため, $G V_{x}, G V_{y}$ は小さくなる. すなわち, 注 目画素に近い画素ほど, より輝度値の差が考虑される.

Sobel フィルタでは注目画素の8 近傍のみに着目しているのに 対し, HED1 では 20 近傍という広範囲に着目しているため, よ り細かな計算が可能である.

\section{3. 2 Harwood Edge Detector 2}

HED2 は, 細線化されたエッジ点を算出する手法である. HED2 は, 横方向, 縦方向それぞれで 4 画素を参照し, それぞ れのエッジ強度を注目画素に足しこむことで, エッジ強度が強く, 連結が強いエッジを抽出できる.

まず, 図 5 のように横方向に隣り合った 4 画素に関して隣同士 の輝度値の差を求める. 図 5 中の 1-2 間の画素値の差を $d x 1$, 2-3 間の画素値の差を $d x 2,3-4$ 間の画素値の差を $d x 3$, 任意に

\begin{tabular}{|c|c|c|c|c|}
\hline & & & \multicolumn{2}{|c|}{ Target Pixel } \\
\hline & 0 & 2 & 5 & \\
\hline 4 & 6 & 8 & 7 & 1 \\
\hline 3 & 9 & 1 & 9 & 3 \\
\hline 1 & 7 & 8 & 6 & 4 \\
\hline & 5 & 2 & 0 & \\
\hline
\end{tabular}
定めた閭値を threshold とする. 以下に HED2 の計算手順を示 す. (a) HED1 filter

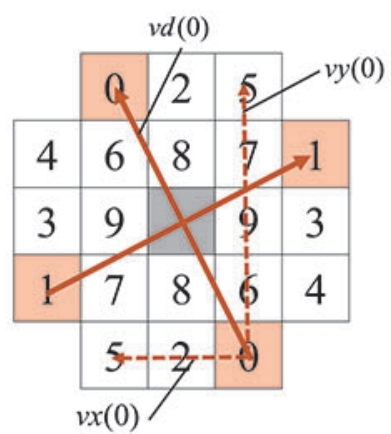

(b) Calculation of $G V_{x}$ and $G V_{y}$
Fig. 4 HED1 filter and Calculation

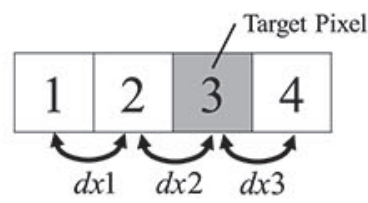

Fig. 5 Calculation of HED2 


\section{HED2 処理手順}

(1) 入力画像に対して漶淡化, および平滑化を行う.

(2) ある座標点の $d x 1, d x 2, d x 3$ を計算する.

(3) 条件 1: $d x 2>$ threshold $/ 3$

条件 2: $d x 2>d x 1$ かつ $d x 2>d x 3$

以上の条件を満たし, $d x 1>0$ ならば $d x 2+=d x 1, d x 3>0$ ならば $d x 2+=d x 3$ とする.

(4) $d x 2>$ threshold ならば $d x 2$ をエッジ点候補とし出力画像に 代入する.

(5) (2)〜 (4)を全座標に対して行う.

(6) (2)〜(5)の処理を横方向, 縦方向に行い, 2 つの出力画像 が得られる.

(7) 2 つの画像の各座標で輝度值を比較し, 大きい值を持つ方 を最終的なエッジとして採用する.

\section{4 学習処理}

3.4.1 モデルデータの作成

学習処理では, まず, 自動車の切り抜き画像から検出対象のモ デルとなるモデル画像を選択し, モデルデータを作成する. 切り 抜き画像のサイズは $30 \times 66$ ピクセルである. モデルデータは

\begin{tabular}{c|c|c}
\multicolumn{3}{|c}{ Table 1 Model data } \\
\hline Model point & Edge direction & Reference vector \\
\hline$m_{1}$ & $\theta_{1}$ & $\left(\Delta i_{1}, \Delta j_{1}\right)$ \\
\hline$m_{2}$ & $\theta_{2}$ & $\left(\Delta i_{2}, \Delta j_{2}\right)$ \\
\hline$\vdots$ & $\vdots$ & $\vdots$ \\
\hline$m_{l}$ & $\theta_{l}$ & $\left(\Delta i_{l}, \Delta j l\right)$ \\
\hline
\end{tabular}

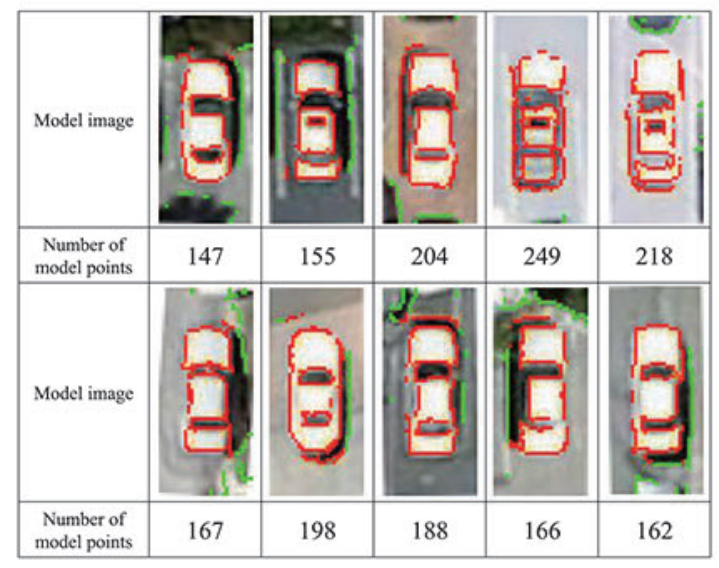

Fig. 6 All model points

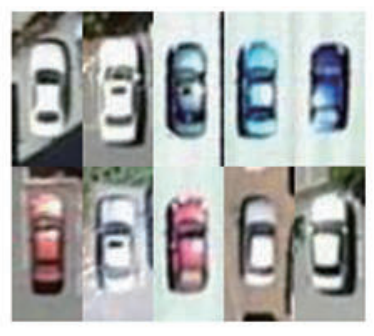

(a) Vehicle images

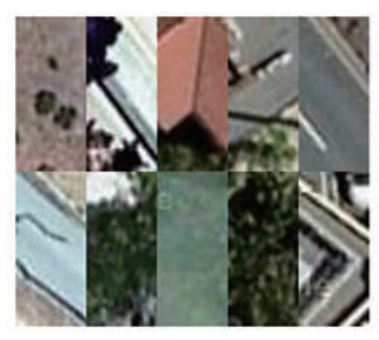

(b) Background images
Fig. 7 Calculation of HED2
GHT の R-table と同様にエッジ方向 $\theta_{m}$ と基準点までのベクトル $\left(\Delta i_{m}\right.$, $\left.\Delta j_{m}\right)$ を登録することで物体の形状を学習する. エッジ方向, ベクトル の抽出を行うエッジ点をモデル点と呼ぶ. 本研究では自動車切り抜き 画像の中心点を基準点に設定した. また, モデル画像は 10 枚選択し， 座標 $(5,8)$ から座標 $(23,55)$ の範囲内に存在するエッジ点からモデル データを作成した. 総モデル点数を $l$ とするとモデルデータは表 1 の ようになる. 選択されたモデル点を図 6 示す. 画像中の赤点が選択 されたモデル点である.

\subsection{2 モデルデータのマッチング}

PLS HT の学習処理では検出対象であるポジティブクラス, 非 検出対象であるネガティブクラスの投票パターンを PLS 回帰分 析を用いて学習する. 本研究では, ポジティブクラスには衛星写 真から切り出した自動車画像，ネガティブクラスには自動車以 外の背景部分をランダムに選択した画像を使用して学習を行っ た. モデル画像と同様に，切り抜き画像のサイズは $30 \times 66$ ピク セルである. 自動車画像と背景画像の一部を図 7 に示す.

モデルデータ作成後, すべての学習画像に対しモデルデータ のマッチングを行う。ママッング処理では, GHT と同様にモデ ルデータを参照し，投票処理を行う.

GHT との造いは，投票值を累櫴するのではなく，投票パター ンを作成するということにある. 投票パターンを記述するために, 学習画像の座標ごとに総モデル点数と同じ長さのビット列を用意 する. 座標点に対して投票されれば，投票に関与したモデル点に 対応したビット列の要素に 1，投票が無ければ 0 を記述すること で投票パターンを得る. マッチングの流れを図 8 に示す.

まず, 学習画像の各座標にモデル点の数と同じ長さのビット 列を用意し，全て 0 で初期化する. 学習画像からエッジ画像を 抽出し, エッジ方向を算出する. あるエッジ点のエッジ方向が $\theta_{1}$ であったとする. モデルデータ内でエッジ方向が $\theta_{1}$ であるモデ ル点 $m_{1}$ が, 基準点までのベクトル $\left(\Delta i_{1}, \Delta j_{1}\right)$ という情報を持つ場 合, 現在注目しているエッジ点から $\left(\Delta i_{1}, \Delta j_{1}\right)$ 方向の座標のビット 列を参照し，モデル点 $m_{1}$ に対応する要素を 1 にする. また，投 票点が決定し，投票を行う際，図 9(a) に示すような，投票点を

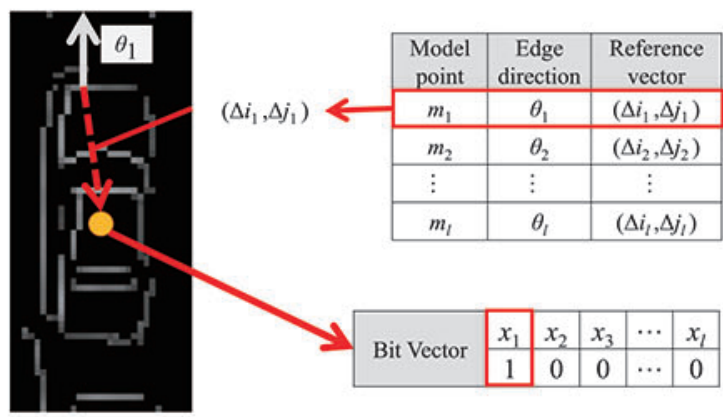

Fig. 8 Matching

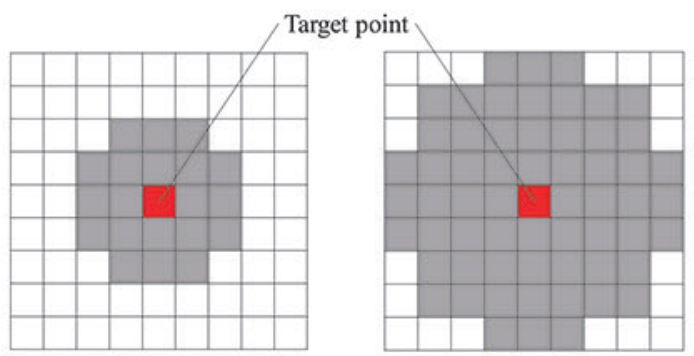

(a) Voting range

(b) Non-Maximal Suppression range

Fig. 9 Range of vote and NMS

1142 精密工学会誌/Journal of the Japan Society for Precision Engineering Vol.83, No.12, 2017 
中心とする直径 5 画素の円内の座標に対しても同様の投票処理 を行う.このように投票に幅をもたせることで, 多少の形状の個 体差を吸収することができる. この処理を全てのエッジ点に対 して行う.

\subsection{3 回帰モデルの作成}

マッチング処理後, その結果を用いて PLS 回帰分析の説明変 数, 目的変数に用いる学習データを作成する. 目的変数にはクラ スラベル, 説明変数にはマッチング処理で得られたビット列を 学習画像一枚につき一つ取り出して用いる.

ポジティブクラスの場合は画像の中心部分に検出に有効なモ デル点からの投票が集まるため, 図 9(b)の範囲で各座標の投票 数に対して非極大点抑制を行い, 画像の中心に最も近いピーク 点のビット列を抽出する. ネガティブクラスの場合は画像の中 心のビット列を抽出する.

取り出したビット列は行ベクトルとして結合し, 学習画 像枚数 $N \times$ 総モデル点数 $L$ の行列を作成する. この行列を PLS 回㷌分析の説明変数 $\boldsymbol{X}$ に用いる.

$$
\begin{gathered}
\boldsymbol{X}=\left(\begin{array}{ccc}
x_{1,1} & \cdots & x_{1, L} \\
\vdots & \ddots & \vdots \\
x_{N, 1} & \cdots & x_{N, L}
\end{array}\right) \\
x_{n, l}=\left\{\begin{array}{l}
1 \\
0
\end{array}\right.
\end{gathered}
$$

また目的変数 $\boldsymbol{y}$ には, ポジティブクラスであるものに+1, ネガティブクラスであるものにー1のクラスラベルを用いて 表現する. 行列 $\boldsymbol{y}$ は学習画像枚数 $N \times 1$ の行列である ${ }^{7)}$.

$$
\boldsymbol{y}=\left(\begin{array}{c}
y_{1} \\
y_{2} \\
\vdots \\
y_{N}
\end{array}\right) \quad y_{n}=\left\{\begin{array}{c}
+1 \text { (Positive class) } \\
-1 \text { (Negative class) }
\end{array}\right.
$$

説明変数 $X$ と目的変数 $y$ を図 10 に示す. $X$ と $\boldsymbol{y}$ をそれぞれ平 均值で中心化し, 標準偏差で正規化することで標準化する. これ らを入力データとして PLS 回帰分析を行うと, 回帰係数 $\boldsymbol{b}$ が求ま り, 自動車と背景を分ける識別器が完成する. このようにして得 られた回帰係数 $\boldsymbol{b}$ は各投票の重みを表す.

$$
\boldsymbol{b}=\left(\begin{array}{c}
b_{1} \\
b_{2} \\
\vdots \\
b_{L}
\end{array}\right)
$$

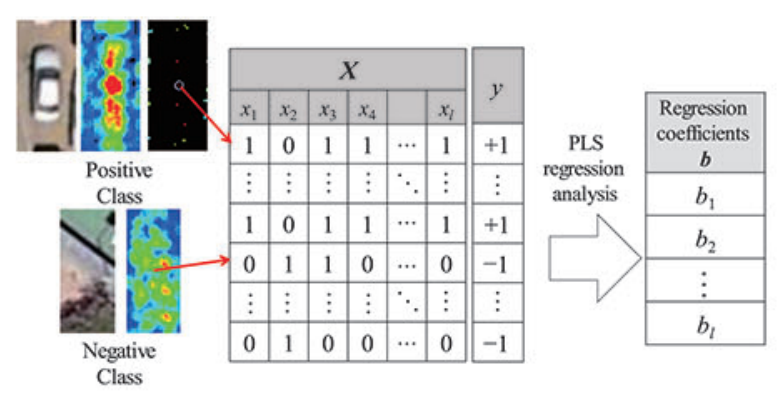

Fig. 10 Making the predictor variables and the response variables

\section{5 検出処理}

検出処理では, 学習処理から求まった回帰係数を投票重み として, 入力画像に対して GHT を適用し物体を検出する.

まず，入力画像に対して学習と同じくエッジ検出処理を行 いエッジ点とエッジ方向を求め, 学習処理と同様にモデルデ 一タのマッチングを行う. 検出処理の投票処理でも学習処理 同様, 図 9(a)の籁囲に投票を行う. マッチングを行うことで 入力画像の全座標に対して投票パターンを得ることができ る. この投票パターンと学習処理で求めた回帰係数より, 推 定值を導出する. 推定值 $y$ が +1 に近い值をとればポジティブ クラス, -1に近い值をとればネガティブクラスとなる.

また, 学習処理では自動車の向きをそろえて学習している ため, 検出処理ではモデルデータを回転させて複数回検出処 理を行うことで, 自動車の回転を考虑した検出を行っている. 回転角度を $\varphi$ とすると, モデルデータに記録されている各モ デル点の基準点までのベクトル $(\Delta i, \Delta j)$ は回転を考虑し, 式(7) を用いて算出された $\left(\Delta i^{\prime}, \Delta j^{\prime}\right)$ を使用する.

$$
\left(\begin{array}{l}
\Delta i^{\prime} \\
\Delta j^{\prime}
\end{array}\right)=\left(\begin{array}{cc}
\cos \varphi & -\sin \varphi \\
\sin \varphi & \cos \varphi
\end{array}\right)\left(\begin{array}{l}
\Delta i \\
\Delta j
\end{array}\right)
$$

画像中の全座標に対して推定值を求めることで, 推定值パ ラメータ空間を作成する.この推定值パラメータ空間に対し, 非極大点抑制, ピーク抽出, 閾值処理を順に行う. 検出処理の 流れを図 11 に示す.

最後に, 後処理として検出枠の重なり領域に着目し, オーバー ラップしている検出点候補の除去を行う. 図 12 に示すように, ま ず，二つの検出枠の重なり領域を算出する. 重なり領域が検出枠 のある一定以上であれば，二つの検出点の推定值が小さい方を削

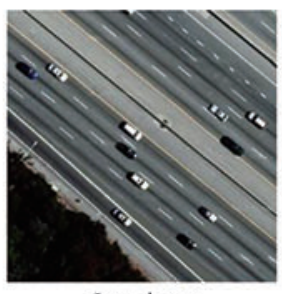

Input image
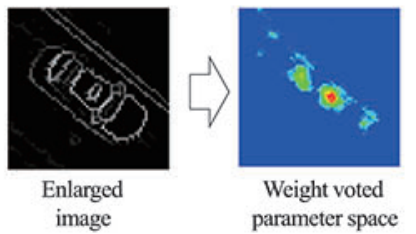

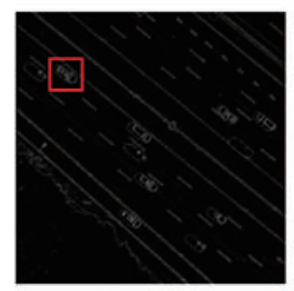

Edge image

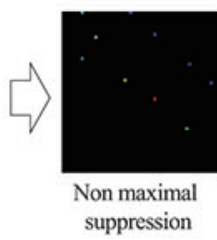

Fig. 11 The overall flow of detection process

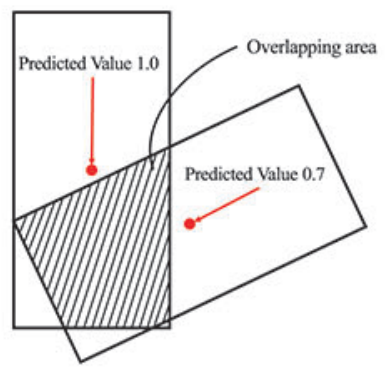

Fig. 12 Deletion of overlapping 
除する. 本研究では, 重なり面䅡比を変化させ実験を行い, 一番 精度が高くなった $46 \%$ 以上の重なりがあった場合に除去を行った.

\section{4. 特徵選択法}

自動車部分の全てのエッジ点をモデル点として採用する場合, モデル点の数が膨大になってしまい, 計算コストの増加や, 推定 精度が低下寸る原因となる. そのため, 本章では, 回州係数 b, VIP(Variable Influence on Projection)を用いて全モデル点の中から, 重要なモデル点を選択する方法を提案する. 本章で説明する特 徵選択は, 学習処理で行う.

\section{1 類似モデル点の除去}

まず, 全モデル点から類似しているモデル点の除去を行う. 複 数の自動車の切り抜き画像からモデル点を選択したとき，同じ 座標に似たようなエッジ方向を持つモデル点が複数存在する. そのため, モデルデータに登録されているエッジ方向と基準点 までのベクトルが似通ってしまい, 対応する投票結果も類似し てしまう. 重要度を用いた特徵選択を行う際, 類似したモデル点 が存在していると重要度も似た值を持ち, 同じ位置のモデル点 ばかりが選択される.これにより自動車全体の形状を捉えきる ことができなくなってしまい, 精度低下の原因となる. そのた め, モデル点の座標が一致し, エッジ方向が \pm 5 度以内に存在す る場合は, 類似モデル点の中から 1 つだけを残し, それ以外を 除去した.

\section{2 重要度による特徵選択}

類似モデル点を除去した後, PLS 回帰分析によって得られる 重要度を用いて特徵選択を行う. 本稿では回帰係数 $\boldsymbol{b}$ およびVIP を用いた特徵選択を取り上げる. なお, 回帰係数 $\boldsymbol{b}$, VIP は PLS 回师分析の圧縮次元数によって值が異なり, 特徵選択に最適な 圧縮次元数が存在する. そこで, 本研究では PLS 回带分析の圧 縮次元数を 1 10 で変化させて特徴選択を行った.

4.2 .1 回帰係数 $\boldsymbol{b}$ を用いた特徵選択

PLS 回帰分析で求められた回帰係数 $\boldsymbol{b}$ は各特徵点の重みとし ての役割も果たしている. 本研究では PLS 回㷌分析の目的変数 に自動車であれば+1, 背景であれば-1を用いている. そのため, 回帰係数の值が正であれば自動車にマッチするモデル点であり, 負の值であれば背景にマッチしやすいモデル点である. また, 回 州係数の絶対值が大きいほど嬂別に有効なモデル点であり, 0 に 近いほど嬂別には有効でないモデル点であることを表している. そのため, 回帰係数 $\boldsymbol{b}$ を用いて特徵選択を行う際は, 回帰係数 $b$ の絶対值を重要度として, 重要度の大きい順に特徵を選択する.

まず, 類似点を除去した後のモデルデータを用いて PLS 回帰 分析を行うことにより回㷌係数を算出し, その絶対值をとる. 次 にその絶対值の大きい順にソートする. 最後に回帰係数の大き い順に上位 $m$ 個の特徽点を選択し, 新しいモデルデータとする. 回帰係数 $\boldsymbol{b}$ による特徵選択の流れを図 13 に示す. このモデルデ ータを使い, 再度学習処理を行う.
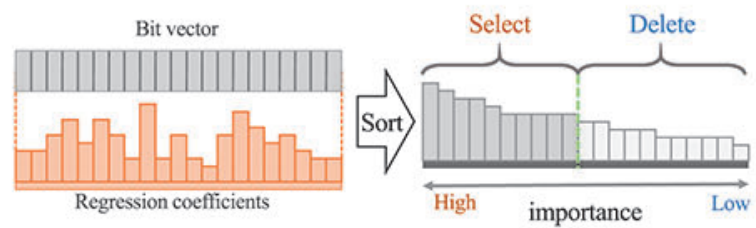

Fig. 13 Feature selection by regression coefficients

\subsubsection{VIP を用いた特徵選択}

VIP とは, PLS 回帰分析によって得られるパラメータを用い て求められる, 各特徵の重要度を表す指標である. 特徵ベクトル $X$ のある要素 $x_{k}$ に対応寸る $V I P_{k}$ は式(8)のように求めることがで きる.

$$
\begin{gathered}
V I P_{k}=\sqrt{\frac{K \sum_{a=1}^{A} V_{a}^{2} W_{k a}^{2}}{\sum_{a=1}^{A} V_{a}^{2}}} \\
V_{k}=\boldsymbol{U}_{k}^{f} \boldsymbol{T}_{k}
\end{gathered}
$$

$\begin{array}{ll}K & : \boldsymbol{X} \text { の特徴次元数 } \\ A & : P L S \text { 圧縮次元数 } \\ \boldsymbol{W} & : \text { PLS により求められた相関行列 }(K \times A) \\ \boldsymbol{U} & : P L S \text { により求められた } \boldsymbol{y} \text { のスコア } \\ \boldsymbol{T} & \text { :PLS により求められた } \boldsymbol{X} \text { のスコア }\end{array}$

$V I P_{k}$ の值が大きい特徵 $x_{k}$ は, 目的変数 $y$ の解析能力が高いこ とを表す. VIP で特徵選択を行う場合も前項と同様に PLS 回崹 分析を行い, PLS のパラメータから VIP を算出する. その後, 図 13 と同様に VIP の值が大きい順にソートし, 上位 $n$ 個の特 徵点を選択し, 新しいモデル点とする. その後, 再度学習処理を する.

\section{5. 実験}

\section{1 データセット}

実験には, Google Earth Sun Francisco Data Set を使用した ${ }^{7)}$.こ のデータセットには解像度 $2048 \times 2048$ の衛星画像が 23 枚含ま れている. 衛星画像の一部を図 14 に示す. この 23 枚の衛星画 像を学習用 4 枚と検出用 19 枚に分割し, 実験を行った. 学習画 像として用いる画像はこのデータセットから切り抜いた画像を 使用している. 学習画像のポジティブクラスの作成は, 正解デー タから作成する. 正解データには, 衛星画像中に存在する自動車 の中心座標と自動車の四隅の座標点が格納されている. 自動車 の四隅の座標点から回転角を求め, 衛星画像を回転する. その 後, 正解データの中心座標を画像中心にし, 縦 66pixel×横 30pixel となるように自動車画像を切り抜く.また, 今回はセダン車のみ を学習画像としている.

\subsection{PLS HT の検出実験}

本研究では, 精度評価の指標として $\mathrm{F}$ 值を用いた. F 值とは, Precision(適合率)と Recall(再現率)の総合的な評価の際に利用さ れる尺度のことである. F 值は Recall と Precision の調和平均に
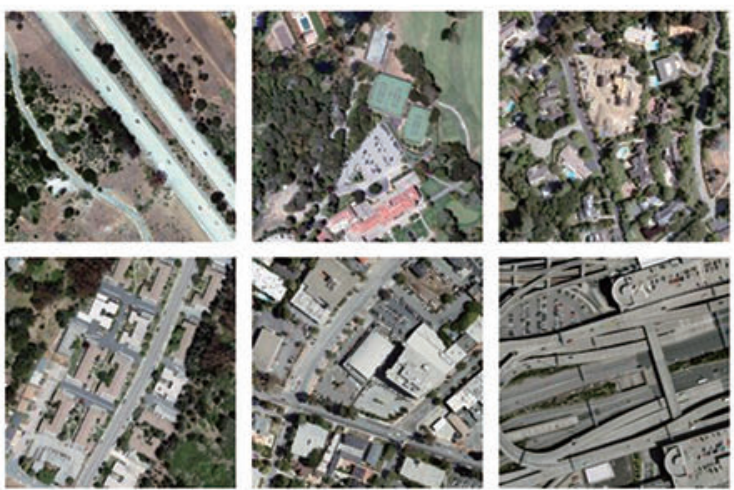

Fig. 14 Google Earth Sun Francisco Data Set 
よって算出される. Recall は衛星画像中に存在する自動車のうち 検出できた割合, Precision は実際の検出点のうち検出点が自動 車であった割合である. 以下の式(9), 式(10), 式(11)で Recall, Precision, F 值を求めることができる. Recall を Re, Precision を $P r, \quad \mathrm{~F}$ 值を $F$ とする. また, 自動車の検出数を $T P$, 見逃し数を $F P$, 誤検出数を $F N$ とする.

$$
\begin{gathered}
R e=\frac{T P}{T P+F N} \\
P r=\frac{T P}{T P+F P} \\
F=\frac{2 R e P r}{R e+P r}
\end{gathered}
$$

本研究では，モデルデータ作成用のモデル画像を自動車の切 り抜き画像から 10 枚選択し，モデルデータを作成した. このと き, 全モデル点は 1854 点であった.

学習画像はポジティブクラス, ネガティブクラスに各 200 枚, 各 300 枚, 各 400 枚, 各 500 枚の 4 パターンを用意し, 実験を 行った. 本稿では一番精度が高かった各 300 枚ずつを用いた場 合の結果を示す. また, 衛星画像では太陽の当たり方で一方向の みに影が出て, 偏りが生じるため, 反転した画像を共に学習画像 に含めることで影の付き方なども均等に学習することができる. ポジティブクラスにはセダン車の画像 150 枚を左右反転させた 計 300 枚, ネガティブクラスには背景画像 75 枚を上下左右反転 させた計 300 枚の画像を使用して学習を行った. モデルデータ のマッチングを行う際, 自動車の前後を揃えて, 形状を学習して いる. そのため, ポジティブクラスは左右の反転のみを行ってい る. 反対に, ネガティブクラスの場合は前後を考虑する必要が無 いため, 上下左右反転している.

マッチングで作成した各学習画像の投票パターンを入力とし, PLS 回帰分析を行った. その際の圧縮次元数は, 交差検定法を 用いて決定した. 図 15 は, 交差検定法で求まった 10 次元まで の推定值と真值の平均誤差である. 図 15 から圧縮次元数が 2 次 元の場合で真值との誤差が最少になっていることが確認できる. そこで PLS 回帰分析を行う際の圧縮次元数は 2 に設定した.

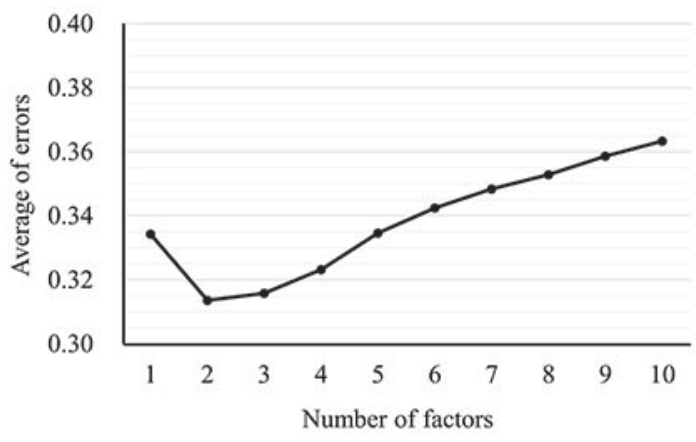

Fig. 15 Result of cross-validation

Table 2 Detection Result

\begin{tabular}{c|c}
\hline Number of correct answers & 1264 \\
\hline Recall & 0.64 \\
\hline Precision & 0.73 \\
\hline True Positive & 812 \\
\hline False Negative & 305
\end{tabular}

学習処理で求まった回帰係数を用いて検出処理を行った. こ のとき回転の分割数を 36 ,つまり $10^{\circ}$ 刻みで検出処理を行った. また, 検出時のピーク抽出の閾值は, 值を変動させ, $\mathrm{F}$ 值が最大 となったときの值を使用した. 本実験ではピーク閾值 0.83 と設 定したとき， F 值が最大となった. 19 枚のテスト画像に対して 検出処理を行った結果を表 2 に示す. 現在はセダン車のみを学 習しているが，画像中に存在する全車両の $64 \%$ を検出できた. 検出結果の一部を図 16, 図 16 中の赤枠 (破線) の拡大画像を図 17 に示寸. 画像内の赤枠は誤検出, 青枠は正解検出を示寸.

\section{$5.3 \mathrm{GHT}$ との比較実験}

PLSHT と GHT の比較実験を行った. PLS HT は前節の検出結 果を用いた. GHT はPLS HT で用いたモデルデータをそのまま $\mathrm{R}$ テーブルとして使用し検出実験を行った. 図 18 に閾值を変化 させた場合の PLSHT と GHT の検出結果を Recall-Precision 曲線 を用いて示す.このグラフでは曲線が右上にあるほど高精度な

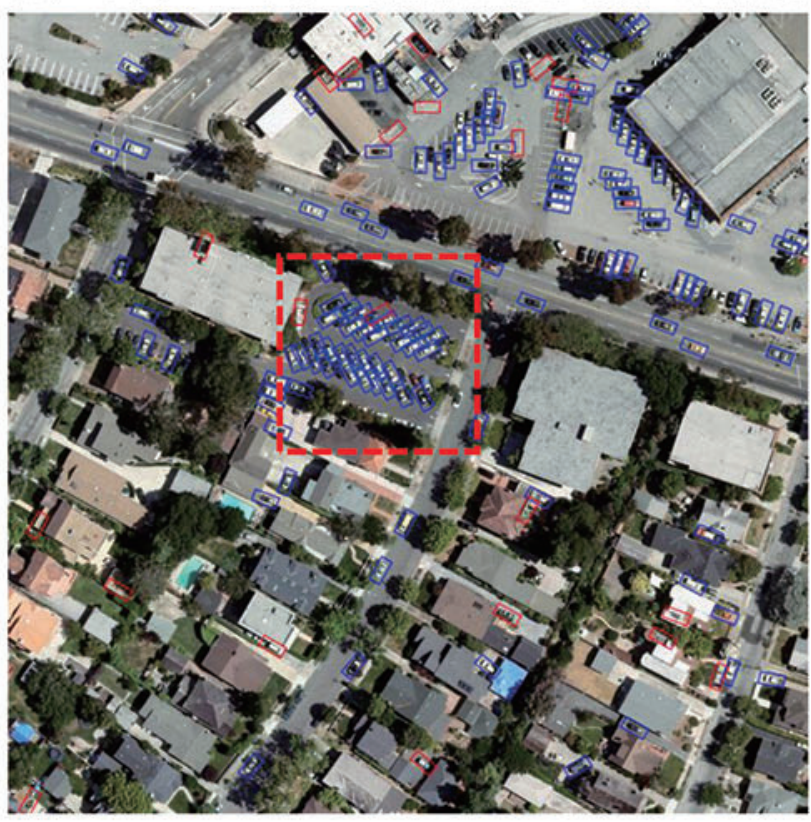

Fig. 16 Result image

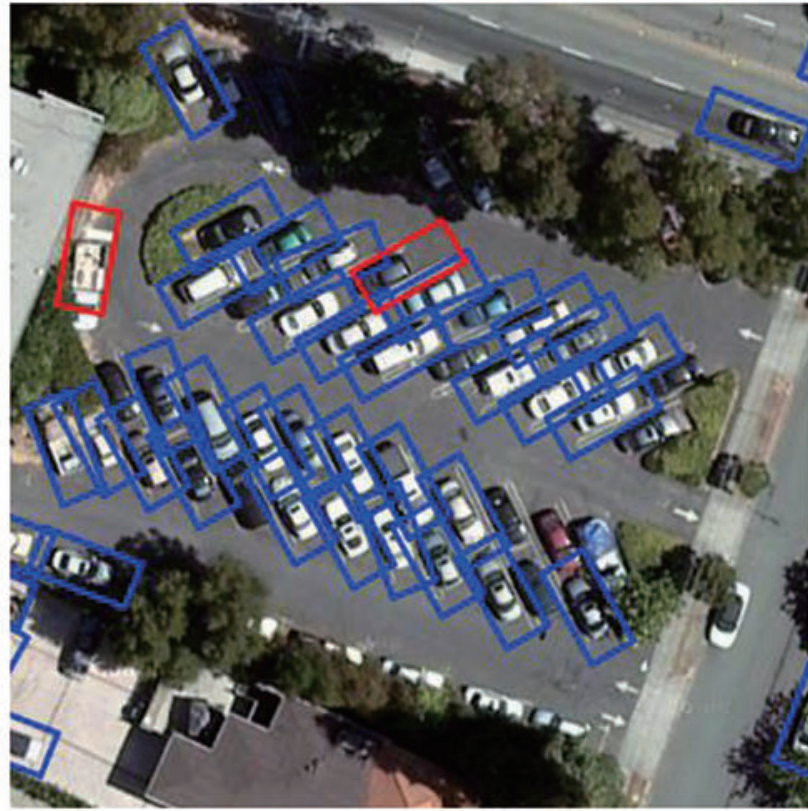

Fig. 17 Enlarged image 
検出である. 図 18 からも分かるように PLS HT は GHT よりも 高精度に検出ができていることが分かる.

GHT の正解検出数が PLS HT の結果と等しくなるようにピ 一ク抽出の閾值を手動で設定した. 表 3 は入力画像での誤検出 の比較結果である. PLS HT では GHT と比べ, 約 $72 \%$ の誤検出 を削隇できた. 図 19 は各手法での検出結果の一部である. 画像 中の青枠, 赤枠はそれぞれ正解検出と誤検出を示している. 図 19 から, PLS HT は GHT に比べ誤検出が抑えられていることがわ かる. GHTではエッジが存在すると必ずどこかに投票されるた め, エッジの密集部分などでは唄検出が起こりやすくなる. 一 方, PLSHT では自動車検出のために重み付けが行われているた め, エッジの密集部分などでも誤検出が抑制できる.

表 4 に計算時間の比較を示す. 計算時間は並列計算を行わず, 1 スレッドで処理を行った場合の衛星画像 1 枚当たりの平均処 理時間である.

前処理は, エッジ検出の処理時間, メインの処理は投票処理か

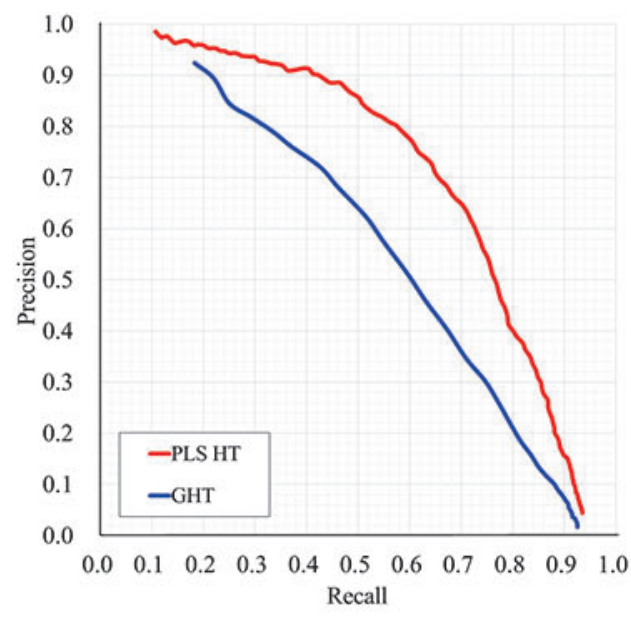

Fig. 18 Comparison the result of PLS HT with GHT

Table 3 Detection result of PLS HT and GHT

\begin{tabular}{c|c|c}
\hline & GHT & PLS HT \\
\hline Number of correct answers & \multicolumn{2}{|c}{1264} \\
\hline Recall & \multicolumn{2}{|c}{0.64} \\
\hline False Negative & 1074 & 305 \\
\hline
\end{tabular}

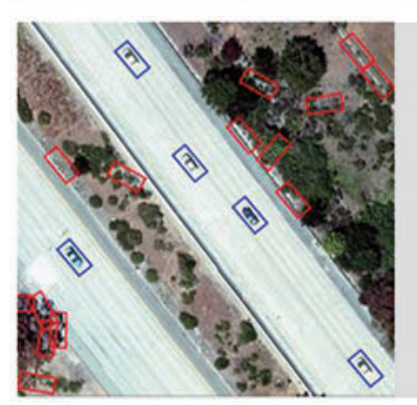

(a)GHT

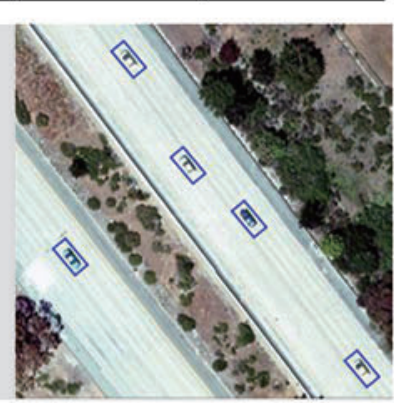

(b)PLS HT
Fig. 19 Comparison the result of PLS HT with GHT

Table 4 Average processing time per an image

\begin{tabular}{c|c|c}
\hline & GHT & PLS HT \\
\hline Preprocessing & \multicolumn{2}{|c}{$3 \mathrm{sec}$} \\
\hline Main process & $51 \mathrm{~min} 5 \mathrm{sec}$ & $75 \mathrm{~min} 46 \mathrm{sec}$ \\
\hline Post processing & $0.8 \mathrm{sec}$ & $0.6 \mathrm{sec}$ \\
\hline \hline Total & $51 \mathrm{~min} 9 \mathrm{sec}$ & $75 \mathrm{~min} 50 \mathrm{sec}$ \\
\hline
\end{tabular}

らピーク抽出までの処理時間, 後処理はオーバーラップ除去の 処理時間を示している.

前処理の時間はどちらも同じ方法を用いているため, 処理時 間の差は見られない. 一方, 投票処理からピーク抽出の部分では 処理時間に大きな差がみられ, GHT では 1 枚の衛星画像あたり 51 分 5 秒, PLS HT では 75 分 50 秒となった. GHT では各座標 に投票の累積を行うだけであるのに対し, PLSHT では投票パタ ーンに対して回带係数を乗算して推定值を求める. この処理の 違いが計算時間の差に影響している. また, 後処理では若干であ るが差がみられた. GHT ではエッジの密集部分に誤検出が多く 存在する.このような場所では検出点が多く存在し, オーバーラ ップ除去に時間がかかるため, 計算時間に差が出てしまう. 後処 理の計算時間は設定するピーク抽出時の閾值によって大きく異 なる.

\section{4 特徵選択実験}

4章で解説した特徵選択法を PLS HT に導入し検出実験を行っ た. まず，全モデル点は 1854 点から 4.1 節で説明したように類 似モデル点の除去を行い, 1460 点のモデル点を得た. この 1460 点のモデル点から重要度による特徵選択を行う. また, 各モデル 点数によって最適な学習画像枚数も異なってくるため, 学習画 像にはポジティブクラス, ネガティブクラス各 200 枚, 各 300 枚, 各 400 枚, 各 500 枚の 4 パターンを用意し, 実験を行った.

この実験では, 特徵選択法を用いて, 1460 点の中から 50 点刻 みで 50〜1400 点まで選択し, 検出結果の比較を行った.

特徵選択を行った結果で一番検出精度が高かったものは, 回 帰係数 $\boldsymbol{b}$ で特徵選択を行った場合, 圧縮次元数 8 で 1250 点を選 択し，学習画像に各 300 枚を用いた場合であった. VIP で特徵選 択を行った場合は, 圧縮次元数 3 で 1300 点を選択し, 学習画像 に各 300 枚を用いた場合であった. 特徴選択を行う前の 1854 点 を用いた場合, 類似点除去後の 1460 点を用いた場合, 重要度を 基に特徵選択を行った場合の検出結果の一部を表 5 に示す. 全 モデル 1854 点を用いた場合の $\mathrm{F}$ 值は 0.68 , 回帰係数 $\boldsymbol{b}$ で 1250 点, VIP で 1300 点を特徵選択し, 検出を行った結果は, それぞ れ 0.70, 0.71 という結果となった. 全てのモデル点を使用する よりも, 特徵選択を行った場合の方が, 検出精度が高いという結 果となった. これは全モデル 1854 点の中に, 検出に不要な特徵 が存在しており, 特徵選択を行うことで検出に有効な特徵のみ でPLS HT を行うことができた結果である.

また, 回帰係数および VIP で特徵選択を行った場合の各モデ ル点での F 值の推移を図 20 に示す. 尚, 各モデル点数で実験を 行い, 圧縮次元数, 学習画像枚数を変化させた中で一番精度の高 い結果を, そのモデル点数の結果として図示した. 図 20 より, 選択するモデル点数が少ない場合は, 回帰係数で特徴選択した 方が検出精度が良い結果となり, 選択数が 400 点を超えてから は, どちらの方法で特徵選択を行っても, ほぼ同等の結果となっ た. これらの中で, 一番検出精度が高いものはVIP で 1300 点を 選択した場合であった.

表 5, 図 20 からモデル点数を 700 点程度にしても検出精度は, 全モデル 1854 点を用いた場合の検出精度とほぼ同等となった. PLS HT では使用するモデル点数がそのまま投票数に関わって くるため, 少ないモデル点数であるほど, 処理時間が短くなる. つまり, 全モデル 1854 点から特徵選択で 700 点を選択すること で, 検出精度を保ちつつ, 処理時間を約 2.5 倍にすることが可能 である. 全モデル 1854 点を使用した場合, 衛星画像 1 枚あたり の平均処理時間は 75 分 50 秒であり, 特徵選択で 700 点を選択 
Table 5 Part of detection results

\begin{tabular}{r||c}
\hline \hline \multicolumn{1}{c||}{ Number of model points } & F-measure \\
\hline \hline 1854 & 0.68 \\
\hline \hline 1460 & 0.69 \\
\hline $1300 \quad($ Selected by VIP) & 0.71 \\
\hline $1250 \quad($ Selected by $\boldsymbol{b})$ & 0.70 \\
\hline $700 \quad($ Selected by $\boldsymbol{b})$ & 0.69 \\
\hline $150 \quad($ Selected by $\boldsymbol{b})$ & 0.64 \\
\hline
\end{tabular}

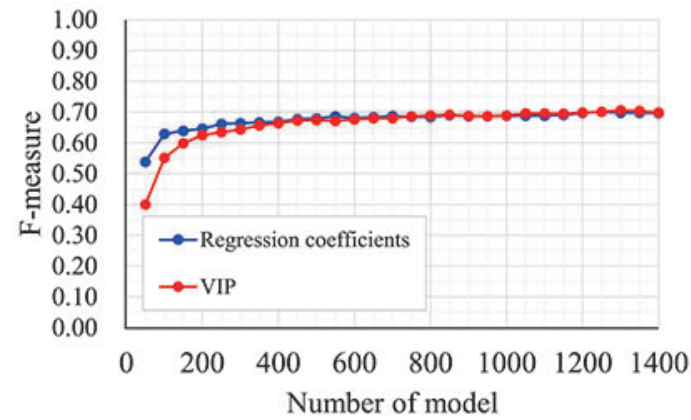

Fig. 20 Discrimination accuracy of each models

Table 6 Comparison of processing time

\begin{tabular}{c||c}
\hline Number of model points & Processing time \\
\hline \hline 1854 & $75 \mathrm{~min} 50 \mathrm{sec}$ \\
\hline 700 & $28 \mathrm{~min} 16 \mathrm{sec}$ \\
\hline 150 & $5 \mathrm{~min} 59 \mathrm{sec}$ \\
\hline
\end{tabular}

した場合の処理時間は 28 分 16 秒であった. 全モデル 1854 点の 中から回帰係数 $\boldsymbol{b}$ を用いて 150 点を選択した場合, $\mathrm{F}$ 值は 0.68 から 0.64 一低下してしまう。しかし，4\%の検出精度の低下を許 容すれば処理時間を 5 分 59 秒に抑えることができる. 表 6 に衛 星画像 1 枚あたりの平均処理時間を示す.

特徴選択を行うことで, 精度向上ならびに処理時間の短縮が 可能であることを確認した.

\section{6. 結 言}

本稿では, GHT の形状変化に弱いという問題点の解決策とし て PLS HT を提案した. まず, 検出対象のモデルデータを作成 し, それを学習画像群に対しマッチングを行う手順を示した. 次 に, マッチングの結果から投票パターンを抽出し, 2 クラス識別 器を作成する手順を示した. 衛星画像からの自動車検出に PLS HT を適用した結果, GHT よりも高精度に検出ができているこ とを確認した.

また，物体検出に最適な特徵だけを用いて PLS HT を行うた めに特徴選択法を提案した. まず, すべての特徴から類似した特 徵を除去する方法を示した. 次に, 2 クラス識別器を作成する際 に得られるパラメータを用いて, 回帰係数, VIP を算出し, これ らを基に特徵を決定する手順を示した. 実験から, 特徵選択を行 うことで, 精度向上ならびに計算時間の短縮が可能であること を確認した.

今回，主成分回帰分析など，他の回帰分析手法を投票重みに 使用した場合と比較を行っていないため, 確認する必要がある. また, 本手法を用いることで, どの程度の隐蔽に対応することが できるのか検証していく必要がある.さらに, 今回は回帰係数 $b$,
VIP を用いて特徵選択を行ったが，特徵選択法を検討する必要 があると考える。

本稿の実験では, セダン車のみを学習に用いて実験を行った. 今後の課題として, セダン車以外のバンやワゴン, これらと大き さの異なるバスやトラックなども学習に加えて実験を行う必要 がある.

本稿では PLS HT の精度評価のため衛星画像からの自動車検 出に適用した．PLSHT は自動車検出以外にも，歩行者検出や顔 検出などにも応用が期待できる.これらの検出対象に対しても， 本手法の有効性を確認する必要がある.

\section{参 考 文 献}

1) P.V.C. Hough : Method and means for recognizing complex patterns, U.S.Patent, 306954 (1962).

2) J. Illingworth, J. Kittler : A Survey of the Hough Transform, Computer vision, graphics, and image processing, 44, 1 (1988) 87.

3) 森本, 興水: Hough 変換の諸課題と新しいパターン計測 基整編, 計測と制御, 35, 11 (1996) 869 .

4) P. Mukhopadhyay, B.B.Chaudhuri : A survey of Hough Transform, Pattern Recognition, 48, 3 (2015) 993.

5) D.H.Ballard: Generalizing the Hough transform to detect arbitrary shapes, Pattern Recognition, 13, 2 (1981) 111.

6) S. Wold, M. Sjöström, L. Eriksson : PLS-regression: a basic tool of chemometrics, Computer Vision and Pattern Recognition (2001) 109.

7) Aniruddha Kembhavi, Larry S. Davis, David Harwood : Vehicle Detection Using Partial Least Squares, IEEE Trans of PAMI, 33, 6 (2011) 109.

8) R.Teofilo, J. P. A. Martins, M. M. C. Ferreira : Sorting variables by using informative vectors as a strategy for feature selection in multivariate regression, Journal of Chemometrics, 23, 1 (2009) 32

9) V.F. Leavers : The dynamic generalized Hough transform: its relationship to the probabilistic Hough transforms and an application to the concurrent detection of circles and ellipses, CVGIP Image understanding, 56, 3 (1992) 381.

10) P.-F. Fung, W.-S. Lee, I. King : Randomized generalized Hough transform for 2-D gray scale object detection, The 13th International Conference on Pattern Recognition, IEEE, 2 (1996) 511.

11) D.M. Tsai : An improved generalized Hough transform for the recognition of overlapping objects, Image Vis. Comput, 15, 12 (1997) 877.

12) A. Kimura, T. Watanabe: An extension of the generalized Hough transform to realize affine-invariant two-dimensional (2D) shape detection, The 16th International Conference on Pattern Recognition, IEEE, 1 (2002) 65.

13) A. Samal, J. Edwards : Generalized Hough transform for natural shapes, Pattern Recognition Letters, 18, 5 (1997) 473.

14) N. Bonnet : An unsupervised generalized Hough transform for natural shapes, Pattern Recognition, 35, 5 (2002) 1193.

15) H. Izadinia, F. Sadeghi, M.M. Ebadzadeh : Fuzzy generalized Hough Transform invariant to rotation and scale in noisy environment, Fuzzy Systems, FUZZ-IEEE (2009) 153.

16) B. Leibe, A. Leonardis, B. Schiele : Robust object detection with interleaved categorization and segmentation, International Journal of Computer Vision, $77,1-3$ (2008) 259

17) S. Maji, J. Malik : Object detection using a max-margin hough transform, Computer Vision and Pattern Recognition (2009) 1038.

18) J. Gall, V. Lempitsky : Class-specific hough forests for object detection, Computer Vision and Pattern Recognition (2009).

19) J. Gall, N. Razavi, L.V. Gool : An Introduction to Random Forests for Multi-class Object Detection, 11 (2012) 243

20) Y. Murai, Y. Yamauchi, T. Yamashita, H. Fujiyishi : Weighted Hough Forest for object detection,Machine Vision Applications (MVA), 14th IAPR International Conference, IEEE (2015) 122.

21) A. Tran, A.Manzanera : Fast growing hough forest as a stable model for object detection,Image Processing Theory Tools and Applications (IPTA), 6th International Conference, IEEE (2016).

22) A. Tejani, D. Tang, R. Kouskouridas, T-K. Kim: Latent-class Hough forests for $3 \mathrm{D}$ object detection and pose estimation, European Conference on Computer Vision. Springer International Publishing (2014) 462.

23) C. Sahin, R. Kouskouridas, T-K. Kim : Iterative Hough Forest with Histogram of Control Points for 6 DoF Object Registration from Depth Images, Intelligent Robots and Systems (IROS), IEEE/RSJ International Conference, IEEE (2016).

24) P. Geladi, B. Kowalski : Partial Least-Squares Regression: A Tutorial, Analytica Chimica Acta, 185 (1986) 